\title{
Neem: a magical herb in endodontics
}

\author{
Harpreet Singh, Mandeep Kaur, Jaidev Singh Dhillon, Munish Batra, Jyotsna Khurana \\ Department of Conservative Dentistry and Endodontics, Gian Sagar Dental College and Hospital, Patiala 140401, India.
}

Correspondence to: Dr. Harpreet Singh, Department of Conservative Dentistry and Endodontics, Giansagar Dental College and Hospital, Patiala 140401, India. E-mail: hsgentledental@gmail.com

How to cite this article: Singh H, Kaur M, Dhillon JS, Batra M, Khurana J. Neem: a magical herb in endodontics. Stomatological Dis Sci 2017;1:50-4.

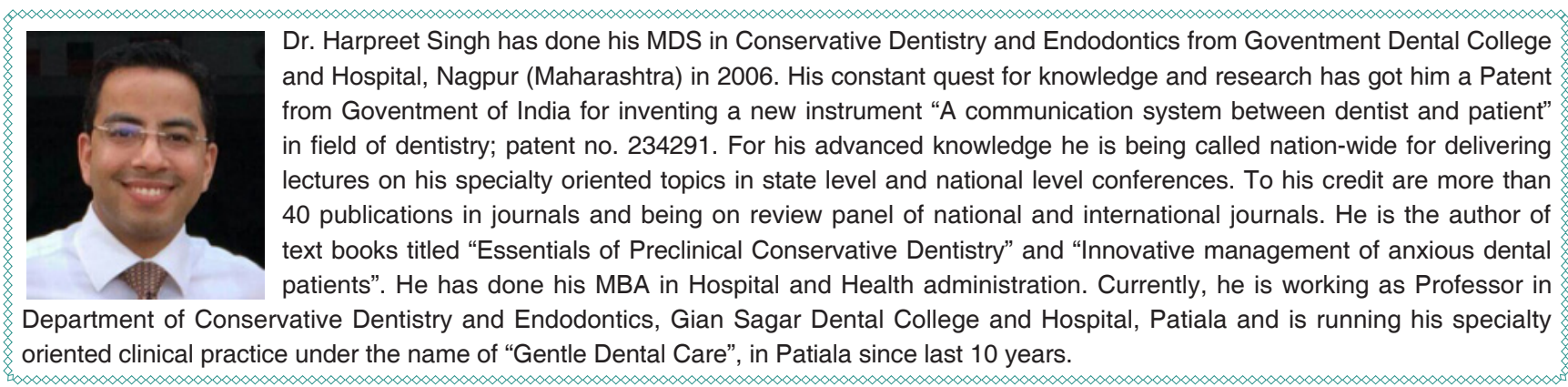

Article history:

Received: 08-12-2016

Accepted: 07-02-2017

Published: 29-06-2017

Key words:

Endodontics,

herbs,

neem

\begin{abstract}
For thousands of years, humans have been using herbal remedies to cure and prevent various illnesses. Out of many herbal products, neem has numerous properties which have promoted its use in both the medical and dental fields. Use of neem has been mentioned in alternative medical specialties, such as Ayurveda, Unani and Homeopathic medicine. Endodontic therapy aims to eliminate microorganisms from the root canal system. In endodontics, irrigating solutions play a significant role because of their antimicrobial activity. Their use becomes even more significant when handling infected endodontic cases where a plethora of microbes is invading the root canal system. However, one has to be extremely cautious while using irrigating chemicals in endodontics, owing to their toxic effects, in case they extrude into periradicular tissue. For this very reason, the use of herbal irrigating solutions such as neem is being advocated worldwide. This article highlights the origin, taxonomy, chemical composition, and medicinal properties of the neem tree and its potential use as an irrigating solution in the field of endodontics.
\end{abstract}

\section{INTRODUCTION}

The use of plants and plant products with medicinal value in the Hindu culture are mentioned in "Rigvedas". Neem has been extensively used in various alternative medical specialties such as Ayurveda, Unani and Homeopathic medicine. ${ }^{[1]}$ Neem (Azadirachta indica, A. Juss) is a tree which belongs to the Meliaceae family and is considered to be a holy medicinal tree found in India. It is also known as "Indian neem/

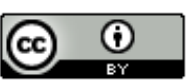

This is an open access article licensed under the terms of Creative Commons Attribution 4.0 International License (https://creativecommons.org/licenses/by/4.0/), which permits unrestricted use, distribution, and reproduction in any medium, as long as the original author is credited and the new creations are licensed under the identical terms.

For reprints contact: service@oaepublish.com

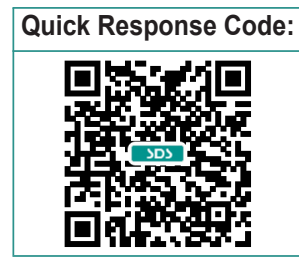


Table 1: Chemical composition of neem

\begin{tabular}{|c|c|}
\hline Isoprenoids & Non-isoprenoids \\
\hline Diterpenoids & Proteins (amino acids) \\
\hline $\begin{array}{l}\text { Triterpenoids containing } \\
\text { protomeliacins, limonoids, } \\
\text { azadirone and its derivatives }\end{array}$ & Carbohydrates (polysaccharides) \\
\hline Gedunin and its derivatives & Sulphurous compounds \\
\hline Vilasinin type of compounds & $\begin{array}{l}\text { Polyphenolics such as flavonoids } \\
\text { and their glycosides }\end{array}$ \\
\hline \multirow{2}{*}{$\begin{array}{l}\text { Csecomeliacins such as } \\
\text { nimbin, nimbinin, nimbolide, } \\
\text { sodium nimbidate, salanin and } \\
\text { azadirachtin }\end{array}$} & Dihydrochalcone \\
\hline & $\begin{array}{l}\text { Coumarin and tannins } \\
\text { Aliphatic compounds }\end{array}$ \\
\hline
\end{tabular}

margosa tree" or "Indian Lilac" and "Persian Lilac". ${ }^{[2]}$ It possesses a wide range of biological activities, such as anti-inflammatory, antimalarial, antimicrobial, antiviral, antifungal, antipyretic, antioxidant, analgesic, immunestimulant, anti-fertility, anti-acne, anti-hypoglycemic, anti-cancer and nematicidal properties. ${ }^{[3,4]}$ In Sanskrit, it is called "Arishta" which means "reliever of sickness" and hence considered "Sarbaroganibarn". ${ }^{[2,5,6]}$ Neem is a common plant which is cultivated in various parts of India for religious and medicinal reasons. Neem is considered to be a "village dispensary" since every part of the tree including the leaves, bark, and seeds have medicinal properties. ${ }^{[7]}$ US National Academy of Sciences recognized the importance of neem tree in 1992 and entitled neem as "a tree for solving global problems". ${ }^{[2,6]}$

\section{TAXONOMY}

The neem tree was described as $A$. indica by Dr. Jussieu in 1830 , and its taxonomic position is as follows:

Order - Rutales

Suborder - Rutinae

Family - Meliaceae (Mahogany family)

Subfamily - Melioideae

Tribe - Melieae

Genus - Azadirachta

Species - indica

\section{CHEMICAL COMPOSITION}

On chemical investigation of the neem tree by Siddiqui in 1942, nimbin was the first bitter compound isolated from neem oil. After that, 135 other compounds have been isolated from different parts of the neem tree, such as the leaf, the bark, and the seed. ${ }^{[7]}$ The compounds are divided into 2 major classes, isoprenoids and non-isoprenoids, which are described in Table 1. The biological activity of each and every compound has been described in Table 2. ${ }^{[2,8]}$
Table 2: Biological activity of chemical compounds

\begin{tabular}{|c|c|c|}
\hline Neem compound & Source & Biological activity \\
\hline Nimbidin & Leaf & $\begin{array}{l}\text { Anti-inflammatory } \\
\text { Antiarthritic } \\
\text { Antipyretic } \\
\text { Hypoglycemic } \\
\text { Antigastric ulcer } \\
\text { Spermicidal } \\
\text { Antifungal } \\
\text { Antibacterial } \\
\text { Diuretic }\end{array}$ \\
\hline Sodium nimbidate & Leaf & Anti-inflammatory \\
\hline Nimbin & Seed oil & Spermicidal \\
\hline Nimbolide & Seed oil & $\begin{array}{l}\text { Antibacterial } \\
\text { Antimalarial }\end{array}$ \\
\hline Gedunin & Seed oil & $\begin{array}{l}\text { Antifungal } \\
\text { Antimalarial }\end{array}$ \\
\hline Azadirachtin & Seed & Antimalarial \\
\hline $\begin{array}{l}\text { Gallic acid, epicatechin and } \\
\text { catechin }\end{array}$ & Bark & $\begin{array}{l}\text { Anti-inflammatory and } \\
\text { immunomodulatory }\end{array}$ \\
\hline $\begin{array}{l}\text { Margolone, margolonone and } \\
\text { isomargolonone }\end{array}$ & Bark & Antibacterial \\
\hline $\begin{array}{l}\text { Cyclic trisulphide and cyclic } \\
\text { tetrasulphide }\end{array}$ & Leaf & Antifungal \\
\hline Polysaccharides & & Anti-inflammatory \\
\hline Polysaccharides Gla, Glb & Bark & Anti-tumour \\
\hline Polysaccharides Glla, GIIla & Bark & Anti-inflammatory \\
\hline NB-II peptidoglycan & Bark & Immunomodulatory \\
\hline
\end{tabular}

\section{ROLE OF NEEM IN ENDODONTICS}

\section{Preparation of neem leaf extract for endodontic use}

There are several techniques of making the neem leaf extract, ${ }^{[0]}$ however, the most commonly used technique is described here. Twenty-five grams of mature neem leaves need to be collected [Figure 1A] and washed with sterilized distilled water. With $50 \mathrm{~mL}$ of absolute ethanol [Figure 1D] added to the neem leaves and this mixture is macerated for $1-2$ min [Figure 1B]. The extract is filtered through filter paper [Figure 1C]. The extraction process is repeated using the coarse residue with $25 \mathrm{~mL}$ of ethanol and filtered again. Both of the extracts need to be mixed and filtered through fast filter paper. The alcohol portion has to be removed from the extract in a water bath [Figure 1E] until the volume becomes $25 \mathrm{~mL}$. Care is taken not to allow the temperature of water bath to rise above $45-50^{\circ} \mathrm{C}$. The whole procedure usually takes approximately $6 \mathrm{~h}$ for completion. ${ }^{[10]}$ The liquid is now ready to be used as an irrigant and must be stored in an air tight container.

\section{Rationale of using neem as endodontic irrigant}

Antimicrobial drug resistance is a major problem in the medical and dental fields. ${ }^{[7]}$ It is for this reason that health professionals are looking for alternatives, such as herbal products, which possess significant antibacterial properties. Of all these natural medications, neem is drawing significant attention since the plant possesses 

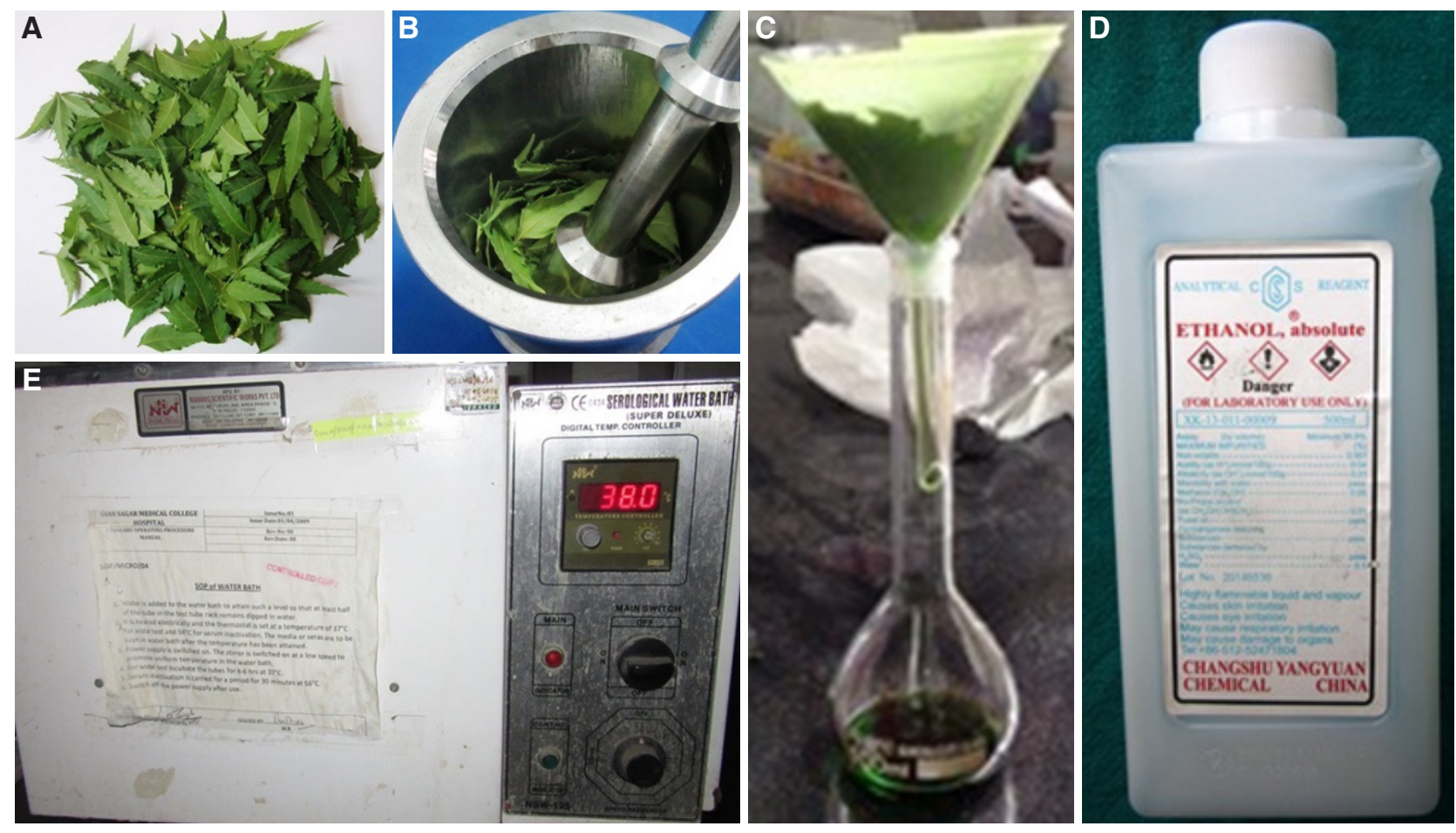

Figure 1: (A) Neem leaves; (B) maceration of neem leaves; (C) filtration process; (D) ethanol; $(E)$ water bath

excellent antibacterial and antifungal properties. ${ }^{[1]}$

Endodontic infections have been studied extensively to highlight their microbial nature to help in managing cases clinically. It has been observed that the obligate anaerobic bacteria dominate the entire bacterial species found in primary infections. ${ }^{[11]}$ Sundqvist ${ }^{[12]}$ confirmed that the microorganisms present in root canal system play an important role in the progression of the periradicular lesion. A major biologic aim of endodontic treatment is to eliminate intracanal tissue and pathogens, aided by antimicrobial substances and optimized root canal obturation. ${ }^{[13,14]}$ The isoprenoid group (nimbin, nimbinin, nimbidinin, nimbolide and nimbidic acid) of constituents of neem has a broad range of therapeutic and antimicrobial effects suggesting its potential as an endodontic irrigant. ${ }^{[6,15,16]}$ The use of neem as an endodontic irrigant may be advantageous because neem is an excellent antioxidant with a very high biocompatibility, and thus there is no risk of tissue toxicity with its use. Biocompatibility of neem to the human periodontal ligament fibroblasts has already been proved, and this is an important factor favoring its clinical application in endodontics. ${ }^{[17]}$ However, the limitation of using this wonder drug is its characteristic bitter taste, which is because of the nimbidin present in neem. This drawback can be overcome by incorporating sweeteners into the neem extract. ${ }^{[15,16]}$

\section{Literature support for using neem extract}

Various studies have been conducted by numerous researchers to evaluate the antimicrobial efficiency of neem leaf extract when used in endodontics. A careful review of these research studies should be completed to draw inferences about the clinical use of the neem leaf extract in endodontics.

Bohora et al. ${ }^{[6]}$ in 2010 compared the antibacterial efficacy of the neem leaf extract and $2 \%$ sodium hypochlorite against $E$. faecalis and $C$. albicans. For this in vitro study, Brain Heart Infusion agar plates were prepared, and respective bacterial cultures were spread onto agar plates. Wells of $6 \mathrm{~mm}$ diameter were prepared. With $50 \mu \mathrm{L}$ of the respective irrigant (ethanol as the control) was added to the respective wells and the plates were incubated for $24 \mathrm{~h}$ at $37^{\circ} \mathrm{C}$. They found that there was a significant difference between the zone of inhibition of neem leaf extract and the $2 \% \mathrm{NaOCl}$ against $E$. faecalis and a mixed culture. No significant difference was observed against $C$. albicans.

Hegde et al. ${ }^{[10]}$ in 2013 compared the antibacterial efficacy of $2 \%$ sodium hypochlorite, propolis, neem leaf extract, turmeric and liquorice against $E$. faecalis and $C$. albicans, using the agar diffusion method. They concluded in their study that the neem leaf extract showed the highest zone of inhibition against $E$. faecalis and C. albicans.

Ghonmode et al. ${ }^{[3]}$ in 2013 evaluated the efficacy of neem leaf extracts, grape seed extracts, $3 \%$ sodium hypochlorite, and absolute ethanol, against $E$. faecalis 
culture by performing an agar diffusion test. They found that neem leaf extracts showed significantly greater zones of inhibition as compared to the other test materials. They concluded that the neem leaf extract has a significant antimicrobial effect against $E$. faecalis, commonly found bacteria in the root canal system.

Dutta et al. ${ }^{[15]}$ in 2014 evaluated the in vivo antimicrobial efficacy of $2.5 \%$ sodium hypochlorite and $0.2 \%$ chlorhexidine gluconate, and an experimental irrigant formulated from the neem tree. The preoperative and postoperative samples were evaluated for colony forming units after irrigation with test irrigants. It was concluded that neem had good anti-microbial efficacy and could be considered for endodontic use.

In an interesting study by Damre ${ }^{[18]}$ in 2015 in which the antimicrobial efficacy of herbal irrigating agents (neem leaf extract, turmeric, honey, and aloe vera) was evaluated, it was observed that honey showed the highest zone of inhibition against $E$. faecalis. Honey was followed by neem, sodium hypochlorite, turmeric haldi, and aloe-vera. In another study by Arora et al. ${ }^{[19]}$ in 2015 the antimicrobial potential of herbal extracts, namely neem (Azadirachta indica), tulsi (Ocimum sanctum), bitter gourd (Momordia charantia), and arka (Calotropis procera) were used as endodontic irrigants against $E$. faecalis and $C$. albicans. It was observed that bitter gourd demonstrated the maximum zones of inhibition, followed by neem, tulsi, and calotropis for both $E$. faecalis and $C$. albicans.

Chandrappa et al. ${ }^{[20]}$ in 2015 also assessed the antimicrobial activity of herbal medicines (neem extract, tulsi extract) and chlorhexidine. They observed that all of the irrigants expressed significant antibacterial efficiency against $E$. faecalis. Babaji et al. ${ }^{[21]}$ in 2016 in their in vitro analysis, concluded that herbal medicines such as neem, $M$. citrifolia, and $A$. vera showed inhibitory zones against $E$. faecalis. Therefore, these can be used as root canal irrigating solutions. Sundaram et al. ${ }^{[22]}$ and Prasad et al. ${ }^{[23]}$ in 2016 also tested the herbal irrigants including neem for their antibacterial efficacy and had suggested its potential role in the future of endodontics.

In conclusion, it is a fact that the neem leaf extract has significant antibacterial properties. There is considerable support in the literature that favors using neem as an intracanal irrigant. It should be noted that the present studies have been in vitro. Researchers worldwide should explore potential benefits of this "wonder drug". The research should focus on neem's use in the clinical setting. This research may determine neem's best use as an herbal alternative to the chemicals used in endodontics.

\section{Authors' contributions}

Manuscript preparation: H. Singh, M. Kaur, J.S. Dhillon, M. Batra

Literature search: H. Singh, M. Kaur, J.S. Dhillon, M.

Batra, J. Khurana

Concept design: H. Singh, J.S. Dhillon

Manuscript review: M. Kaur

References: J. Khurana

\section{Acknowledgments}

We thank Dr. Jon Wagner for his contribution in language editing.

\section{Financial support and sponsorship}

None.

\section{Conflicts of interest}

There are no conflicts of interest.

\section{Patient consent}

Not applicable.

\section{Ethics approval}

Not applicable.

\section{REFERENCES}

1. Raghavendra SS. Antifungal efficacy of Azadirachtaindica (neem) an in vitro study. Braz J Oral Sci 2014;13:242-5.

2. Biswas K, Chattopadhyay I, Banerjee RK, Bandyopadhyay U. Biological activities and medicinal properties of neem (Azadirachta indica). Curr Sci 2001;82:1336-45.

3. Ghonmode WN, Balsaraf OD, Tambe VH, Saujanya KP, Patil AK, Kakde DD. Comparison of the antibacterial efficacy of neem leaf extracts, grape seed extracts and 3\% sodium hypochlorite against E. faecalis - an in vitro study. J Int Oral Health 2013;5:61-6.

4. Subapriya R, Nagini S. Medicinal properties of neem leaves: a review. Curr Med Chem Anticancer Agents 2005;5:149-6.

5. Alves PD, Brandao MGL, Nunan EA, Viannasoares CD. Chromatographic evaluation and antimicrobial activity of neem (Azadirachta indica A. Juss, Meliaceae) leaves hydroalcoholic extract. Braz J Pharm 2009;19:510-5.

6. Bohora A, Heghe V, Kokate S. Comparison of the antibacterial efficiency of neem leaf extract and $2 \%$ sodium hypochlorite against E. faecalis, C. albicans and mixed culture - an in vitro study. Endodontology 2010;22:8-12.

7. Reddy RR, Kumari K, Lokanatha O, Mamatha S, Reddy D. Antimicrobial activity of AzadirachtaIndica (neem) leaf, bark and seed extracts. Inter J Res Phtyochem Pharmacol 2013;3:1-4.

8. Drabu S, Khatri S, Babu S. Neem: healer of all ailments. Res J Pharm Bio Chem 2012;3:120-6.

9. Nayak A, Nayak RN, Soumya G, Kishore B, Mithun K. Evaluation of antibacterial and anticandidal efficiency of aqueous and alcoholic extract of neem (Azadirachta indica) - an in vitro study. Int $J$ Res Ayurveda Pharm 2011;2:230-5. 
10. Hegde V, Kesaria DP. Comparative evaluation of antimicrobial activity of neem, propolis, turmeric, liquorice and sodium hypochlorite as root canal irrigant against E. faecalis and C. albicans - an in vitro study. Endodontology 2013;25:38-45.

11. Narayanan LL, Vaishnavi C. Endodontic microbiology. J Conserv Dent 2010;3:233-9.

12. Sundqvist G. Associations between microbial species in dental root canal infections. Oral Microbiol Immunol 1992;7:257-62.

13. Padmaja K, Shah A, Malpani S, Kakkar M, Thakkar R. Retreatment in endodontics a review. J Adv Med Dent Sci Res 2015;3:205-8.

14. Cohen S, Burns RC. Pathways of the pulp. New York: Mosby Incorporation; 1998. p. 323.

15. Dutta A, Kundabala M. Comparative anti-microbial efficacy of Azadirachta indica irrigant with standard endodontic irrigants: a preliminary study. J Conserv Dent 2014;17:133-7.

16. Ravishankar P, Laksmi T, Kumar SA. Ethno-botanical approach for root canal treatment-an update. J Phar Sci Res 2011;3:1511-9.

17. Botelho MA, Santos RAD, Martins JG, Carvalho CO, Paz MC, Azenha CR, Ruela R, Queiroz DB, Ruela WS, Marinho G, Ruela FI. Efficacy of a mouthrinse based on leaves of neem in the treatment of patients with chronic gingivitis. J Med Plants Res 2008;2:341-6.

18. Damre PG. Comparative evaluation of antimicrobial activity of herbal vs chemical root canal irrigants against E. faecalis - an in vitro study.
Int $J$ Adv Res 2015;3:1563-72

19. Arora T, Kang RS, Mann JS, Khurana NS, Aggarwal R, Walia G. Antimicrobial activity of herbal extracts against recalcitrant endodontic pathogens: an original in vitro study. Saint Int Dent $J$ 2015;1:28-32.

20. Chandrappa PM, Dupper A, Tripathi P, Arroju R, Sharma P, Sulochana K. Antimicrobial activity of herbal medicines (tulsi extract, neem extract) and chlorhexidine against Enterococcus faecalis in endodontics: an in vitro study. J Int Soc Prev Community Dent 2015;5:S89-92.

21. Babaji P, Jagtap K, Lau H, Bansal N, Thajuraj S, Sondhi P. Comparative evaluation of antimicrobial effect of herbal root canal irrigants (Morinda citrifolia, Azadirachta indica, aloe vera) with sodium hypochlorite: an in vitro study. J Int Soc Prev Community Dent 2016;6:196-9.

22. Sundaram D, Narayanan RK, Vadakkepurayil KA. Comparative evaluation on antimicrobial effect of honey, neem leaf extract and sodium hypochlorite as intracanal irrigant: an ex-vivo study. $J$ Clin Diagn Res 2016;10:ZC88-91

23. Prasad SD, Goda PC, Reddy KS, Kumar CS, Hemadri M, Ranga Reddy DS. Evaluation of antimicrobial efficacy of neem and aloe vera leaf extracts in comparison with 3\% sodium hypochlorite and $2 \%$ chlorhexidine against E. faecalis and C. albicans. J NTR Univ Health Sci 2016;5:104-10. 